(C) 2017 Published by Elsevier Sp. z o.o. on behalf of European Regional Centre for Ecohydrology of the Polish Academy of Sciences.

This manuscript version is made available under the CC-BY-NC-ND 4.0

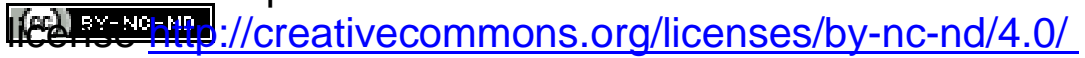

This version available http://nora.nerc.ac.uk/516741/

NERC has developed NORA to enable users to access research outputs wholly or partially funded by NERC. Copyright and other rights for material on this site are retained by the rights owners. Users should read the terms and conditions of use of this material at http://nora.nerc.ac.uk/policies.html\#access

NOTICE: this is the author's version of a work that was accepted for publication in Ecohydrology and Hydrobiology. Changes resulting from the publishing process, such as peer review, editing, corrections, structural formatting, and other quality control mechanisms may not be reflected in this document. Changes may have been made to this work since it was submitted for publication. A definitive version was subsequently published in Ecohydrology and Hydrobiology, 17 (1). 73-83. 10.1016/j.ecohyd.2016.12.006 www.elsevier.com/ 


\title{
Projected novel eco-hydrological river types for Europe
}

\begin{abstract}
Climate change and human use of water abstracted from rivers and groundwater are projected to alter river flow regimes worldwide in coming decades. Consequently, community structure in many rivers is expected to change because river flow is fundamental in determining conditions required by organisms, and processes on which they depend. Future flows in panEuropean rivers were computed for baseline conditions (period 1961-1990) and for different combinations of climate and socio-economic scenarios (2040-2069). For each scenario a set of indicators was produced that describe flow regime aspects that are most important in determining river ecosystem character. Classification techniques were applied to each set to define eco-hydrological river types. Spatial patterns of baseline and future types were mapped. Depending on scenario, about $30-50 \%$ of the river network length remained of the same type, whilst c. $40-50 \%$ transformed to an existing type; a third group of rivers (c. $10-$ $20 \%$ of network length) formed new types, not present under baseline conditions, with potential to create novel river ecosystems.
\end{abstract}

Keywords eco-hydrology; hydro-ecology; river ecosystem; flow alteration; eco-hydrological region; hydro-ecological region; climate change; classification; Europe

\section{Introduction}

Declaration of the current era as the 'anthropocene' (Lewis and Maslin, 2015) highlights that we are in a new human-dominated geological epoch, with the potential to create novel ecosystems (Morse et al., 2014). Human influence over our environment is particularly evident, with most indicators of the state of biodiversity (covering species' population trends, extinction risk, habitat extent and condition, and community composition) showing declines, with no reductions in rate, whereas indicators of pressures (including resource consumption, invasive alien species, nitrogen pollution, overexploitation, and climate change impacts) showed increases (Butchart et al., 2010). In addition, recent changes in climate have altered the ranges of many species (Chen et al. 2011) and the future development of ecosystems that differ in species composition and/or ecological functions from past and present systems is increasingly being recognised (Hobbs et al., 2006; 2009).

Freshwater ecosystems have been identified as particularly degraded (MEA, 2005). Over 30 of the world's 47 largest rivers show major degradation due to water withdrawals exposing $80 \%$ of the world's population to high levels of threat to water security and jeopardising biodiversity (Vorosmarty et al., 2010). In Europe, the threat is primarily to biodiversity; for example, six per cent of common and c. $80 \%$ of rare species are predicted to lose $>90 \%$ of their current range (Markovic et al., 2014). Future climate change is projected to bring higher temperatures and alterations to precipitation in most part of the globe (IPCC, 2014), which will result in changes to the hydrological cycle, including the flow regimes of rivers, with potentially significant implication for water resources and flood risk (Kundzewicz et al., 2008). There is thus the high potential for the creation of novel ecosystems in freshwater environments (Acreman et al., 2014a).

Although many factors influence the type and condition of freshwater ecosystems, including light, water temperature, nutrients and species interactions (Moss et al., 2009), in rivers it is the flow (i.e. discharge, measured as a volume per unit time) that is considered the key factor. Flow controls delivery of nutrients, food and dilution of pollutants and creates riverine habitat that acts as a template (Southwood, 1977) defining characteristics operating at the population 
and community (e.g. species diversity and abundance) levels. The natural flow regime paradigm (Poff et al., 1997) argues that the dynamic character of the natural flow regime of a river - characterised by its magnitude, frequency, duration, timing, and rate of change - is central to sustaining biodiversity and ecosystem integrity (Lytle and Poff, 2004). Modifications to the flow regime alters riverine, riparian and floodplain habitats that can lead to loss of ecosystem services (Okruszko et al., 2011) and there may be limits to hydrological change beyond which significant (or unacceptable) ecological alteration takes place (Richter et al., 1996; Bunn \& Arthington, 2002).

The flow regimes of European rivers vary considerably. Alpine rivers for example are fed by melting snow, have their highest flows in late spring with little flow in winter and are populated by trout (Salmo trutta) and grayling (Thymallus thymallus). In contrast lowland rivers have highest flows in winter and lowest in summer as a result of cyclonic rainfall and support pike (Esox lucius), barbel (Barbus barbus) and sturgeon (Acipenser sturio). European rivers thus form a range of eco-hydrological types, resulting from climate and geology. Centuries of human development across Europe have created major infrastructure projects, such as dams, weirs, diversions and flood protection embankments. Some 47\% of 9,330 European river sites were found to be impacted by multiple pressures and $41 \%$ had altered hydrology (Schinegger et al., 2012).

An assessment of the alteration of flow regimes under climate and socio-economic scenarios showed that European river ecosystems are under significant threat with about two-third at medium or high risk of change (Laizé et al., 2014). Examples of how flow alteration can change river ecosystems can be found in the literature (for example, Lamouroux et al., 2006; Souchon et al., 2008; Poff and Zimmerman, 2010; Feld et al., 2014). Ecosystem services, such as food provision and recreation, of major European floodplains (Okruszko et al., 2011) are particularly vulnerable. This assessment was part of the European Union (EU) project entitled SCENES (water SCenarios for Europe and for NEighbouring States), which investigated the future of freshwater resources up to the 2050s in 'Greater' Europe (defined as EU countries and neighbours i.e. Iceland, Norway, Belarus, Ukraine, Moldova, Turkey, non-EU Balkan countries, and Switzerland) and including the Mediterranean rim countries of north Africa and the near East, from Caucasus to the White Sea (see, for example, Figure 1 below). Laizé et al. (2014) was the first assessment of river ecological risk caused by flow regime alteration considering pan-European geographical coverage, detailed river network, ecologically-relevant hydrological indicators, and combined climate and socioeconomic/policy scenarios (the latter being a particularly innovative aspects of the project, with teams of stakeholders from across Europe producing scenarios of population increase, land management, industrial growth, energy demands and water use for different socioeconomic and policy storylines).

SCENES provided a reference point for long-term strategic planning of pan-European freshwater. However, if it provided the quantification of risks of alterations to in-stream and riparian ecosystems resulting from future changes in river flow regimes, Laizé et al. (2014) did not characterise which eco-hydrological river types (i.e. ecologically-relevant hydrological regimes) are found currently in Europe and would be found in the future, nor how the typology may change (rivers may change type, while types may disappear or new types may appear in the future).

In this paper, we describe broad eco-hydrological river types in Europe for the baseline period 1961-1990 using a set of flow regime indicators that influence the character of river 
ecosystems. Given the high level of human modification to European rivers highlighted above, the baseline river types are based on human-altered historical flows (ie not naturalised). Then, using scenarios that combine future socio-economic and climate change we show how some rivers will change their eco-hydrological type, and new types will be created in Europe by 2050 that are likely to result in novel ecosystems.

\section{Data}

This paper used modelled flow data produced in the SCENES project; this is fully described in Laizé et al. (2014), with only a brief overview given here. Input climate datasets include observed historical climate data for 1961-1990 (Climate Research Unit (CRU), UK), and projected future climate for 2040-2069 ('2050s') from two Global Circulation Models (GCMs) under SRES A2 emission scenario: IPSL-CM4, Institut Pierre Simon Laplace, France ('IPCM4'; warm and dry conditions) and MIROC3.2, Center for Climate System Research, Japan ('MIMR'; warm and wet conditions).

These climate change scenarios were selected to be consistent with four socio-economic scenarios defined by the SCENES project as four different visions of future pan-European freshwaters (taking into account socio-economic and environmental settings, and possible consequences for water quantity and quality): Economy First ('EcF'), economy-oriented towards globalisation and liberalisation; Fortress Europe ('FoE'), closed-border Europe concentrating on common security issues; Policy Rules ('PoR'), stronger coordination of policies at the European level; Sustainability Eventually ('SuE'), transition from globalising market-oriented Europe to environmental sustainability.

Climate input data and socio-economic scenarios were combined within the continental-scale water resource model WaterGAP 3.1 (Water - Global Assessment and Prognosis; University of Kassel, Germany; Alcamo et al., 2003) to generate nine sets of modelled monthly flow time series (baseline and eight scenarios). WaterGAP is a semi-distributed model (5' x 5' grid i.e. about $6 \times 9 \mathrm{~km}^{2}$ in central Europe) consisting of a global hydrological model (terrestrial water cycle) and a global water use model (water withdrawals and water consumption of five sectors: domestic, electricity production, manufacturing industry, irrigation, and livestock).

The Baseline flow series is for the standard 1961-1990 reference period and represents modelled observed flows, ie these are human-altered flows including water usage, not naturalised flows. These historical flows were generated by running WaterGAP (and its water use component) with observed climate data from CRU as input, and by calibrating results against observed data from the Global Runoff Data Centre (GRDC).

The eight future flow series (period of record 2040-2069 termed '2050s'), which represent future flows under various water usage conditions, include four runs for each GCM ('IPCM4' or 'MIMR') with one run for each of the four socio-economic scenarios presented above ('EcF', 'PoR', FoE', 'SuE'). These two sets of four runs take into account factors like land use change, population growth, water usage, etc., consistent with the four socio-economic scenarios.

A subset of 33,368 WaterGAP cells was selected to represent all major European rivers and their tributaries (for example, see Figure 1); each cells is the outlet of a basin or nested subbasin, with the smallest basin being $63 \mathrm{~km}^{2}$. Model run outputs extracted for these cells form the raw dataset of the present paper. 


\section{Methods}

\subsection{Monthly Flow Regime Indicators}

The Monthly Flow Regime Indicators (MFRIs) include 14 metrics capturing all aspects of the flow regime: timing, magnitude, frequency of extremes (Laizé et al., 2014; for detailed list, see Table 1) that are considered to influence the river ecosystem. These indicators were developed to assess Ecological Risk due to Flow Alteration (ERFA) in the SCENES project (Laizé et al., 2014) and are based conceptually on the Indicators of Hydrological Alteration (IHA; Richter et al., 1996) that are used worldwide (Arthington, 2012).

The original IHA are based on 32 daily flow statistics. Given the focus of Laizé et al. (2014) on an extensive pan-European river network (>33,000 sites) and 30-year long records, there was a significant cost (mostly computing time) in using the daily IHA as the basis for deriving ERFA classes, which led to the MFRIs. Laizé et al. (2014) compared daily and monthly metrics, and concluded that MFRIs, although losing sub-monthly flow characteristics that can have a strong influence on river ecosystems (eg peak flows), were an appropriate compromise. Similar considerations applied for the present study; it is noteworthy that even with monthly metrics, the analysis described below was computerintensive and required the use of a high-performance PC.

Seven monthly variables (Table 1) were selected to maintain a similar structure of regime characteristics as with IHA by dropping daily variables not computable or less meaningful at a monthly time step, taking into account expert ecological knowledge, and more performing a redundancy analysis on the the 32 IHA (published literature supplemented by rank-based correlation analysis on subset of c. 700 sites). In particular, based on the redundancy analysis, one monthly mean flow was selected to represent each season (eg January for winter, April for spring).

First the seven hydrological variables (one value per year of record per site; first column in Table 1) are calculated for each river cell and each model run (i.e. nine series of seven annual variables for 30 years and for $>30,000$ sites). Then, these variables are used to derive the MFRIs (second column Table 1), which capture magnitude and variability of each variable as one value across the whole period of record for each cell. Magnitude is described by the median (i.e. $50^{\text {th }}$ percentile), and the variability by the the interquartile range (IQR; i.e. difference between $75^{\text {th }}$ and $25^{\text {th }}$ percentiles) of the annual hydrological variables. This results in nine series of 14 indicators for $>30,000$ sites.

Table 1 Monthly Flow Regime Indicators (MFRIs)

\begin{tabular}{|c|c|c|c|}
\hline $\begin{array}{c}\text { MFRI variables } \\
\text { (one value per year) }\end{array}$ & $\begin{array}{c}\text { MFRI } \\
\text { (one value per record) }\end{array}$ & Flow type & Regime characteristics \\
\hline $\begin{array}{c}\text { Number of months above } \\
\text { threshold }^{\mathrm{a}}\end{array}$ & $\begin{array}{c}\text { Median (1) } \\
\operatorname{IQR}^{\mathrm{d}}(2)\end{array}$ & High flows & Magnitude; Frequency \\
\hline January mean flow & $\begin{array}{l}\text { Median (3) } \\
\text { IQR (4) }\end{array}$ & Seasonal flows & Magnitude; Timing \\
\hline April mean flow & $\begin{array}{l}\text { Median (5) } \\
\text { IQR (6) }\end{array}$ & Seasonal flows & Magnitude; Timing \\
\hline
\end{tabular}




\begin{tabular}{cccc}
\hline July mean flow & Median (7) & Seasonal flows & Magnitude; Timing \\
OQR (8) & Median (9) & Seasonal flows & Magnitude; Timing \\
$\begin{array}{c}\text { Number of months below } \\
\text { threshold }\end{array}$ & Median (11) & Low flows & Magnitude; Frequency \\
$\begin{array}{c}\text { Number of sequences at } \\
\text { least two-month long } \\
\text { below threshold }\end{array}$ & Median (13) & Low flows & Magnitude; Frequency; \\
& IQR (14) & & Duration \\
\hline
\end{tabular}

${ }^{\text {a }}$ Threshold $=$ all-data naturalised Q5 from 1961-1990 $\left(95^{\text {th }}\right.$ percentile $)$

${ }^{\mathrm{b}}$ Threshold $=$ all-data naturalised Q95 from 1961-1990 $\left(5^{\text {th }}\right.$ percentile $)$

'Indicator identification number between parentheses

'IQR: Inter-Quartile Range

\subsection{Classification}

There are many different protocols to apply hydrological classification for ecohydrology, with different approaches more or less suitable depending on data and objectives (Olden et al., 2012). In a data-rich context, such as in the present study (30 years of modelled flows at 30,000 sites), an inductive classification based on statistical similarity in flow metrics in appropriate (Auerbach et al., 2016).

Classification, also called clustering analysis (CA), belongs to the field of multivariate statistics, which includes other techniques like ordination. Multivariate statistics aim at identifying patterns in the data but not deriving inferences. CA specifically aims at identifying clusters (or classes) of similar data-points. A detailed description of clustering statistics can be found in Gordon (1999). For each model run independently, all cells (i.e. $33,368)$ were grouped based on similarity of MFRIs using a two-stage classification (hierarchical followed by non-hierarchical clustering).

Firstly, a matrix is built with the descriptive variables of interest on one side (the 14 MRFIs), and the observations (MFRI values for $>30,000$ cells) on the other side. Then distances between the entries in the descriptive variable space are calculated. Different measures of distance are possible; this paper used Euclidean distances. The resulting matrix is called the dissimilarity matrix (the farther entries are in the variable space, the more dissimilar they are) and is the input to the CA algorithm.

Secondly, as it is common practice with CA, different hierarchical clustering techniques are applied because different CA algorithms generally identify different classes. Statistical usage recommends to retain the technique producing classes of fairly equal size and that can be broadly interpreted physically, within the context of the study (Gordon, 1999). Regarding the former recommendation, while a class with few members is often an artefact due to outlier data, the even-cluster-size requirement should be critically reviewed against expert judgment and a good understanding of the data so that genuine small clusters are not erroneously ignored.

In this study, hierarchical clustering was performed using seven methods: single, average and complete linkages, median, centroid, McQuitty, and Ward. Dendrograms and scree plots (agglomeration schedules) were inspected to assess clustering algorithms' performance, and to decide how many clusters should be retained. These are two complementing types of plots showing how different would be a CA using $n$ clusters from one using $n+1$ clusters. 
Dendograms are hierarchical trees with a single cluster on top (with all entries), branching down, with each individual entries in their own "cluster" at the bottom; the closer are the $n$ and $n+1$ clusters on the tree, the less different they are. They are most useful to assess if clusters are evenly sized. Scree plots are curves with the cumulative difference on one axis and the number of clusters on the other. They usually feature an inflexion point indicating the optimal number of clusters. Resulting clusters were mapped to visually check if they formed broadly consistent geographical units (for example, baseline clusters were qualitatively checked against commonly used eco-regions, or baseline against future clusters). Ward's minimal variance method (Ward, 1963) was found to yield the most physically meaningful and evenly-sized classes, a result consistent with other hydrological studies using CA (e.g. Laize and Hannah, 2010). This method starts with singleton clusters, and at each stage, identifies and merges the pair of clusters that causes the minimum increase in total withincluster variance after merging.

Thirdly, the classification was finalised by applying non-hierarchical clustering. A limitation of hierarchical clustering algorithms is that once an item is assigned to a class, it cannot be reassigned to another class (i.e. clusters cannot be refined once constituted), thus leading to potentially suboptimal solutions. This study followed the standard approach to deal with this limitation i.e. to perform non-hierarchical clustering (k-means) to re-assign across cluster membership, using the hierarchical cluster centres as the starting point. These are the final classes used in this study, with each identified class representing an eco-hydrological type. 


\section{Results}

Using CA techniques, ten classes defining eco-hydrological river types were identified for the baseline, and between seven and ten classes for the future scenarios. The characteristics of each type found were compared by analysing their MFRI simplified distributions (based on $5^{\text {th }}, 50^{\text {th }}$, and $95^{\text {th }}$ percentiles) using visual inspection of distribution plots, and Pearson correlations. This determined whether types defined by the various scenarios were the same or different from those types resulting from classification of the baseline MFRIs.

The EcF scenario ('economy first', ie Europe oriented towards globalisation and liberalisation) lead to eight types for both climate runs. The FoE scenario ('fortress Europe', ie closed-border Europe with focus on security) has ten types under IPCM4 (warm and dry future climate) and nine under MIMR (warm and wet). The PoR scenario ('policy rules', ie stronger European-level policy coordination) gets eight types with IPCM4 and 7 with MIMR. Lastly, SuE ('sustainability eventually', ie transition from market-focus to environmental sustainability) yields ten IPCM4 types and nine MIMR types.

All scenarios feature two new types each, but altogether three new types were found. A brief description of each type and their broad geographical location is given in Table 2 for the baseline and, as an illustration, for the IPCM4 and MIMR EcF 2050 runs only. For example, rivers of Type 1 have a Spring-dominated regime, with low flow magnitude and variability. 
Table 2 Description of eco-hydrological types and their geographical distribution (Baseline and IPCM4 EcF 2050s)

\begin{tabular}{|c|c|c|c|c|}
\hline Type & Description & Baseline & IPCM4 EcF 2050s & MIMR EcF 2050s \\
\hline 1 & $\begin{array}{l}\text { Spring dominated regime; } \\
\text { low flow magnitude \& } \\
\text { variability }\end{array}$ & $\begin{array}{l}\text { North Africa coast, } \\
\text { Spain, northwest-- } \\
\text { southeast axis from } \\
\text { Germany to Turkey }\end{array}$ & $\begin{array}{l}\text { Southern North Africa, } \\
\text { northern and eastern } \\
\text { Europe }\end{array}$ & $\begin{array}{l}\text { Similar plus } \\
\text { southern France-- } \\
\text { Germany-Romania } \\
\text { arc }\end{array}$ \\
\hline 2 & $\begin{array}{l}\text { Spring dominated regime; } \\
\text { medium \& low flow } \\
\text { magnitude and variability }\end{array}$ & $\begin{array}{l}\text { Southeast UK-- } \\
\text { Ukraine axis }\end{array}$ & $\begin{array}{l}\text { Similar but reduced } \\
\text { baseline extent, eastern } \\
\text { France }\end{array}$ & $\begin{array}{l}\text { Reduced extent, } \\
\text { some presence in } \\
\text { North Africa }\end{array}$ \\
\hline 3 & $\begin{array}{l}\text { Low hydrological } \\
\text { extremes (arid) and } \\
\text { limited high extremes }\end{array}$ & Inland North Africa & $\begin{array}{l}\text { Largely disappears, } \\
\text { some presence in } \\
\text { Spain }\end{array}$ & Not present \\
\hline 4 & Winter dominated regime & $\begin{array}{l}\text { Northwest-southeast } \\
\text { axis Ireland, France, } \\
\text { Italy, western Turkey }\end{array}$ & Not present & $\begin{array}{l}\text { UK-western } \\
\text { France-Spain arc, } \\
\text { reduced extend } \\
\text { elsewhere }\end{array}$ \\
\hline 5 & $\begin{array}{l}\text { Severe low hydrological } \\
\text { extremes (arid, non- } \\
\text { perennial) and limited } \\
\text { high extremes }\end{array}$ & Inland North Africa & Similar & Similar \\
\hline 6 & $\begin{array}{l}\text { Low (arid) and high } \\
\text { extremes }\end{array}$ & Inland North Africa & Similar & Similar \\
\hline 7 & $\begin{array}{l}\text { Spring dominated regime; } \\
\text { medium flow magnitude } \\
\text { and variability }\end{array}$ & Northeast Europe & Not present & Not present \\
\hline 8 & $\begin{array}{l}\text { Summer dominated } \\
\text { regime }\end{array}$ & Northern Europe & Not present & Not present \\
\hline 9 & $\begin{array}{l}\text { Spring dominated regime } \\
\text { - low flow magnitude and } \\
\text { variability }\end{array}$ & $\begin{array}{l}\text { Northern Italy, } \\
\text { Austria, southern } \\
\text { Iceland, Scotland, } \\
\text { western Norway }\end{array}$ & $\begin{array}{l}\text { Similar with increase } \\
\text { in Norway, England, } \\
\text { Wales, Iceland }\end{array}$ & $\begin{array}{l}\text { Similar with } \\
\text { increased extent }\end{array}$ \\
\hline 10 & $\begin{array}{l}\text { Low seasonal flow } \\
\text { magnitude but high } \\
\text { seasonal flow variability. } \\
\text { Low extremes and limited } \\
\text { high extremes. }\end{array}$ & Inland North Africa & Not present & Not present \\
\hline 11 & $\begin{array}{l}\text { Winter dominated flow. } \\
\text { Medium flow magnitude } \\
\text { and variability. Low } \\
\text { extremes and limited high } \\
\text { extremes. }\end{array}$ & Not present & $\begin{array}{l}\text { Northern Germany, } \\
\text { Romania and southern } \\
\text { Ukraine }\end{array}$ & Not present \\
\hline 12 & $\begin{array}{l}\text { Winter dominated flow. } \\
\text { High flow magnitude and } \\
\text { variability. Low extremes } \\
\text { and limited high } \\
\text { extremes. }\end{array}$ & Not present & $\begin{array}{l}\text { Spain, western France, } \\
\text { Turkey }\end{array}$ & $\begin{array}{l}\text { Some presence; } \\
\text { mainly in Turkey }\end{array}$ \\
\hline 13 & $\begin{array}{l}\text { Winter dominated flow. } \\
\text { Low flow magnitude and } \\
\text { variability. Severe low } \\
\text { extremes and limited high } \\
\text { extremes. }\end{array}$ & Not present & Not present & $\begin{array}{l}\text { Some presence in } \\
\text { Spain and North } \\
\text { Africa }\end{array}$ \\
\hline
\end{tabular}


Detailed maps of the eco-hydrological types for the baseline and both EcF runs are provided in Figure 1 to 3. Each cell was colour-coded according to its river type derived from CA. Figure 1 shows the river types for the baseline, in which most of Europe is dominated by a six types $(1,2,7,8$, and 9) with the remaining four only existing in North Africa. Spatial patterns of types resulting from the IPCM4 and MIMR EcF scenarios are provided in Figure 2 and Figure 3, respectively. These are fairly representative of all eight scenarios. While there are obviously local differences between runs, overall patterns are as follows: (i) North Africa, Middle Eastern countries, Turkey, most of Russia, the Baltic States, Norway, Iceland, and northern UK have very consistent patterns for all eight runs; (ii) Sweden, Finland, northern Russia have consistent patterns for five runs, but differ for IPCM4 FoE, and both SuE runs due to the presence of Class 8, which has otherwise disappeared; (iii) most of Central Europe (from Poland to Albania, from Ukraine to Macedonia, and Austria), plus Switzerland, northern Italy, and south-eastern France feature clear distinct patterns for IPCM4 v MIMR but not major differences between socio-economic scenarios; (iv) the remainder of Western Europe (Ireland, southern UK, Ireland, most of France, Belgium, the Netherlands, Denmark, Germany, Portugal, Spain, southern Italy) features more varied patterns.

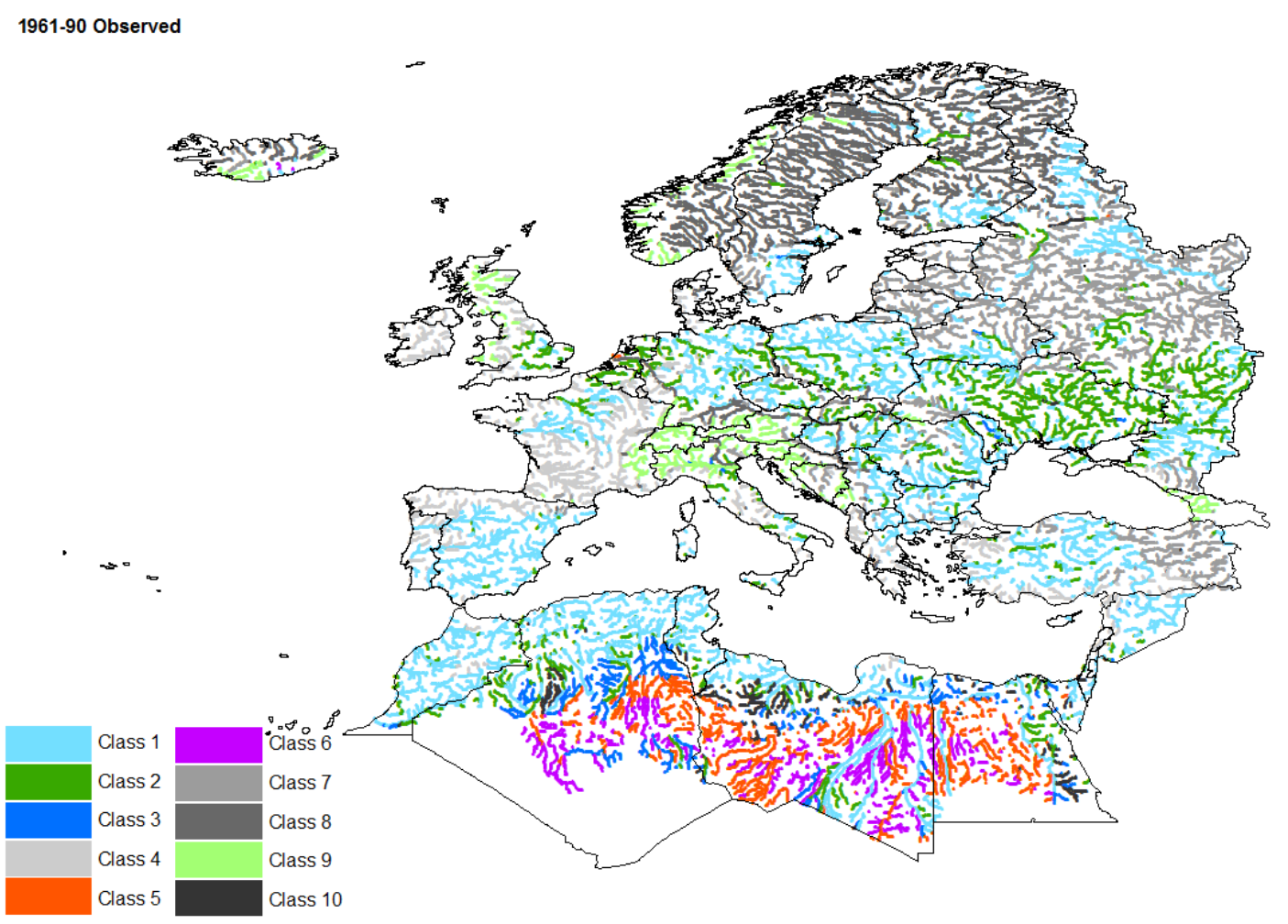

Figure 1 Baseline 10 classes 


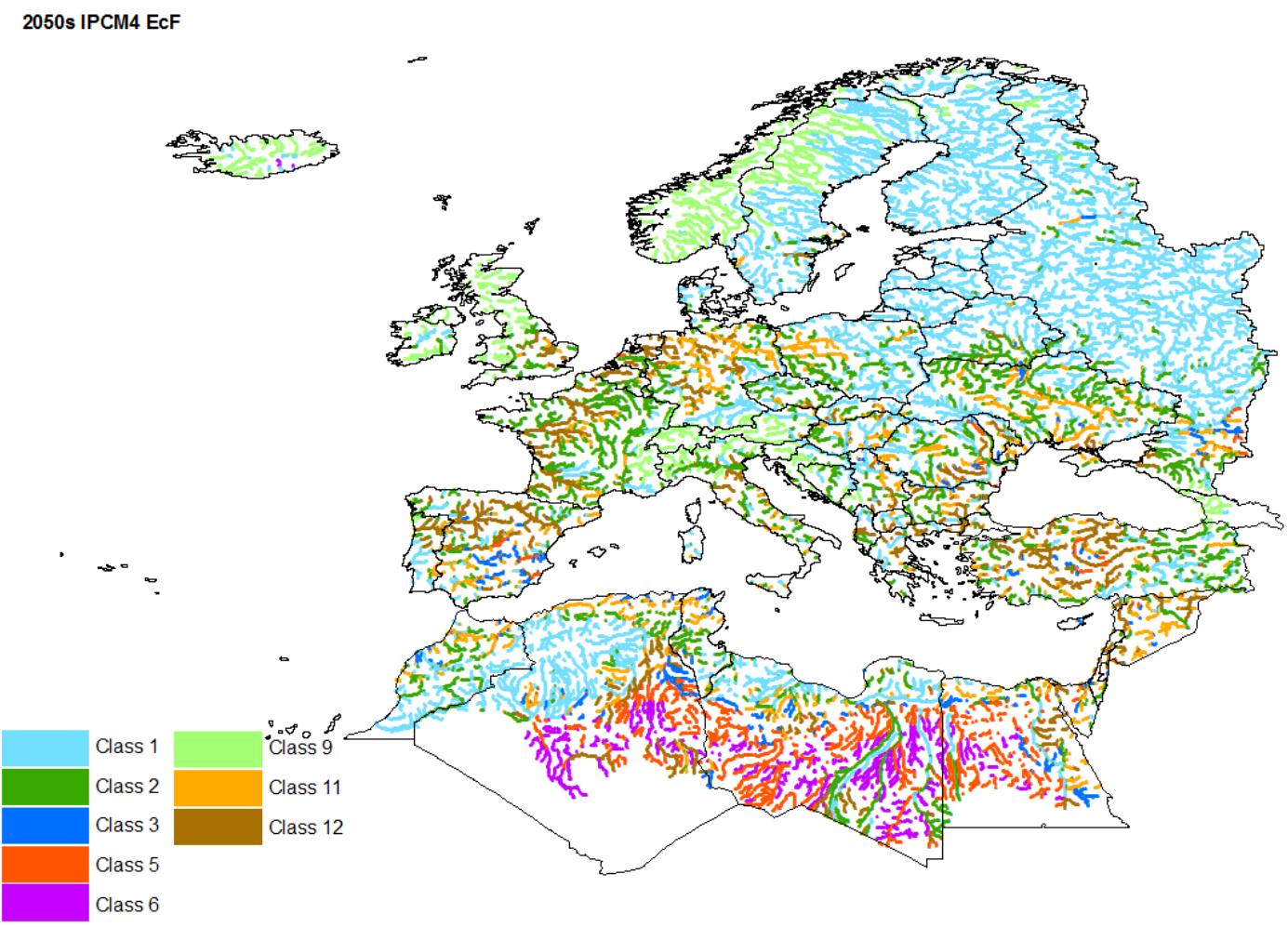

Figure 2 IPCM4 EcF 2050s 8 classes (6 existing, 2 new)

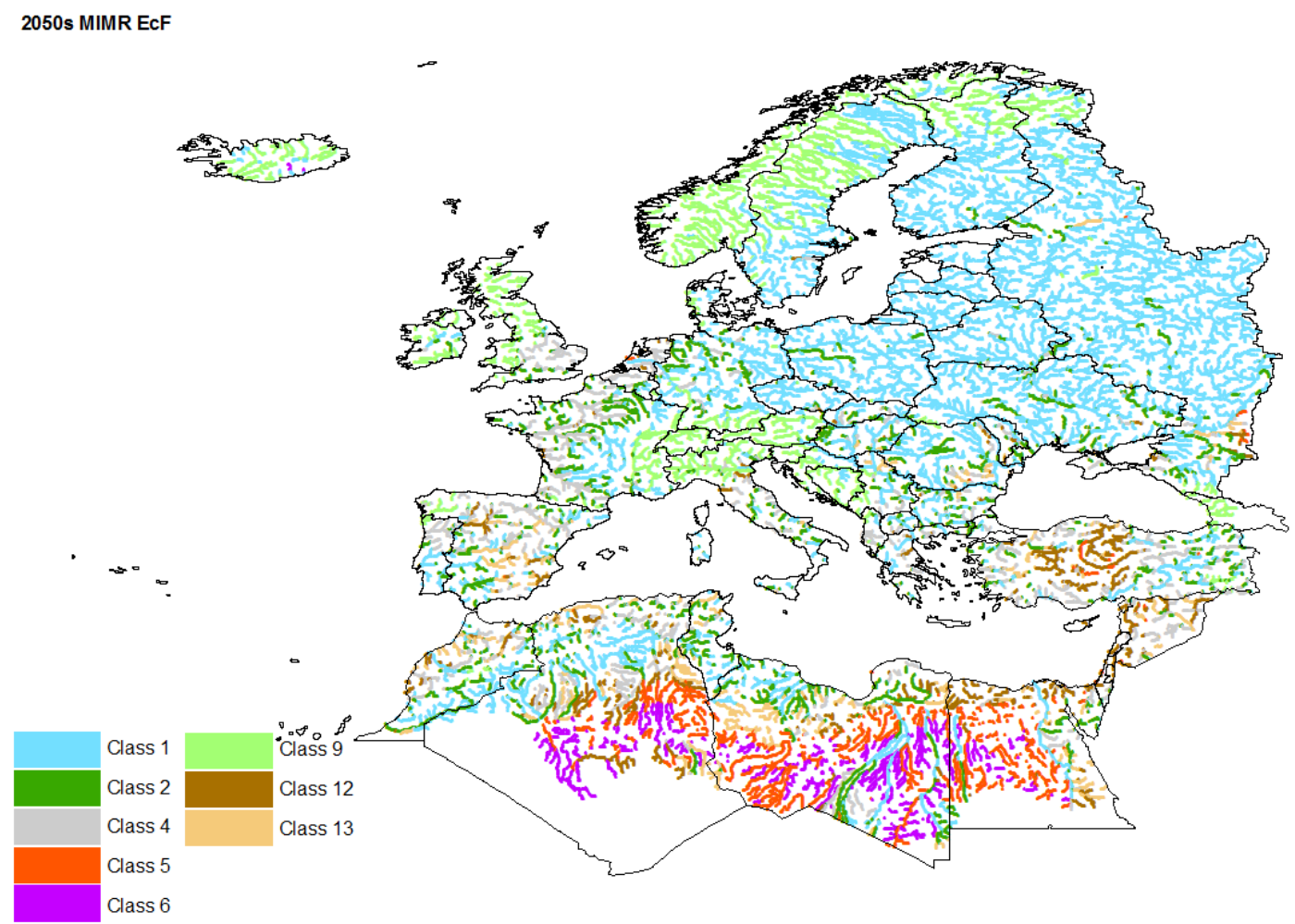

Figure 3 MIMR EcF 2050s 8 classes (6 existing, 2 new) 
Breakdowns of eco-hydrological types (as percentage of the total river network) were derived (see Table 3). Overall, breakdown differences are primarily between climate models, then between scenarios (eg MIMR runs all have more Class 1 and 9 cells river, but the presence of Class 8 seems especially linked to SuE), which is consistent with Laizé et al. (2014). Many of the types $(1,2,3,5,6$ and 9) were found in all the runs, whereas types 4, 7, 8 and 10 were found in the baseline, but not all the scenarios ( 7 and 10 disappear altogether). It is noteworthy that types 11 and 12 were only found in the scenarios and did not exist in the baseline MFRIs. Results for MIMR show that a further new type (13) resulted that was neither in the baseline nor in the IPCM4 scenarios.

Table 3 Breakdowns eco-hydrological river types for baseline and eight 2050s scenarios (X indicates a disappearing type)

\begin{tabular}{|c|c|c|c|c|c|c|c|c|c|c|}
\hline \multicolumn{2}{|c|}{ Type } & \multicolumn{9}{|c|}{$\%$ of River Network } \\
\hline & & \multirow[t]{2}{*}{ Baseline } & \multicolumn{4}{|c|}{ IPCM4 } & \multicolumn{4}{|c|}{ MIMR } \\
\hline & & & EcF & FoE & PoR & SuE & EcF & FoE & PoR & SuE \\
\hline \multirow[t]{10}{*}{ Existing } & 1 & 28 & 41 & 26 & 43 & 27 & 44 & 44 & 47 & 34 \\
\hline & 2 & 14 & 18 & 16 & 19 & 14 & 12 & 14 & $x$ & 11 \\
\hline & 3 & 3 & 3 & 2 & 2 & 2 & $\mathbf{x}$ & 2 & $\mathbf{x}$ & $\mathbf{x}$ \\
\hline & 4 & 8 & $\mathbf{x}$ & 9 & $x$ & 9 & 10 & 3 & 16 & 6 \\
\hline & 5 & 6 & 7 & 6 & 7 & 6 & 6 & 6 & 6 & 6 \\
\hline & 6 & 5 & 5 & 5 & 5 & 5 & 5 & 5 & 5 & 5 \\
\hline & 7 & 15 & $\mathbf{x}$ & $\mathbf{x}$ & $x$ & $x$ & $\mathbf{x}$ & $x$ & $x$ & $\mathbf{x}$ \\
\hline & 8 & 15 & $\mathbf{x}$ & 20 & $x$ & 21 & $\mathbf{x}$ & $x$ & $x$ & 23 \\
\hline & 9 & 4 & 9 & 5 & 9 & 5 & 13 & 13 & 14 & 6 \\
\hline & 10 & 2 & $X$ & $x$ & $x$ & $x$ & $x$ & $x$ & $x$ & $X$ \\
\hline \multirow[t]{3}{*}{ New } & 11 & & 9 & 7 & 9 & 6 & & 7 & & \\
\hline & 12 & & 9 & 4 & 6 & 5 & 5 & 7 & 6 & 6 \\
\hline & 13 & & & & & & 4 & & 5 & 3 \\
\hline
\end{tabular}

The numbers of cells changing river types from baseline to 2050s runs are as follows: (i) from around a third up to nearly half of cells do not change river type (within $30-45 \%$ for IPCM4 and within 35-49\% for MIMR); (ii) around half of cells shift to an existing baseline river type (44-51\% for IPCM4, 42-55\% for MIMR); (iii) approximately 10-20\% of cells shift to a new river type (11-18\% for IPCM4 and 9-13\% for MIMR); see Table 4.

Table 4 Summary of changes in eco-hydrological river types between baseline and the eight 2050s scenarios (typology change colours refers to maps in Figures 4 and 5)

\begin{tabular}{|c|c|c|c|c|c|c|c|c|}
\hline \multirow[t]{3}{*}{ Typology Change } & \multicolumn{8}{|c|}{$\%$ of River Network } \\
\hline & \multicolumn{4}{|c|}{ IPCM4 } & \multicolumn{4}{|c|}{ MIMR } \\
\hline & $\mathrm{EcF}$ & FoE & PoR & $\mathrm{SuE}$ & $\mathrm{EcF}$ & FoE & PoR & $\mathrm{SuE}$ \\
\hline $\begin{array}{c}\text { No change } \\
\text { (green on maps) }\end{array}$ & 30 & 44 & 31 & 45 & 35 & 35 & 35 & 49 \\
\hline $\begin{array}{l}\text { Change to existing type } \\
\text { (blue on maps) }\end{array}$ & 51 & 46 & 53 & 44 & 55 & 51 & 54 & 42 \\
\hline $\begin{array}{l}\text { Change to new type } \\
\text { (red on maps) }\end{array}$ & 18 & 11 & 16 & 11 & 9 & 13 & 11 & 9 \\
\hline
\end{tabular}


The spatial distribution of river type direction of change from baseline to 2050 conditions was mapped (no type change, change to an existing type, change to a new type). For IPCM4 EcF (Figure 4), it can be seen that most of northern and north-eastern Europe changes to an existing type (for example, 5 expands in Norway), whilst much of North Africa, the Alps, Poland and northern UK stay unchanged. There is a zone arching from Spain through north and west France, southeast UK, into the Netherlands and northern Germany, and extending to Russia via Poland and Ukraine where novel eco-hydrological types appear, as is also the case along the western coast of Black Sea and in central Turkey. For MIMR (Figure 5), patterns are very similar except that there are no new types appearing in the UK-France-GermanyPoland zone. In addition, and similarly to the river type geographical patterns described above, overall change patterns for all eight scenarios can be summarised as follows: (i) North Africa, Middle Eastern countries, Turkey, Russia, the Baltic States, Iceland, and northern UK have very consistent change patterns; (ii) Sweden, Finland, Norway have consistent patterns for five runs but differ for IPCM4 FoE, and both SuE runs; (iii) Central Europe shows the IPCM4 v MIMR difference between change patterns. 


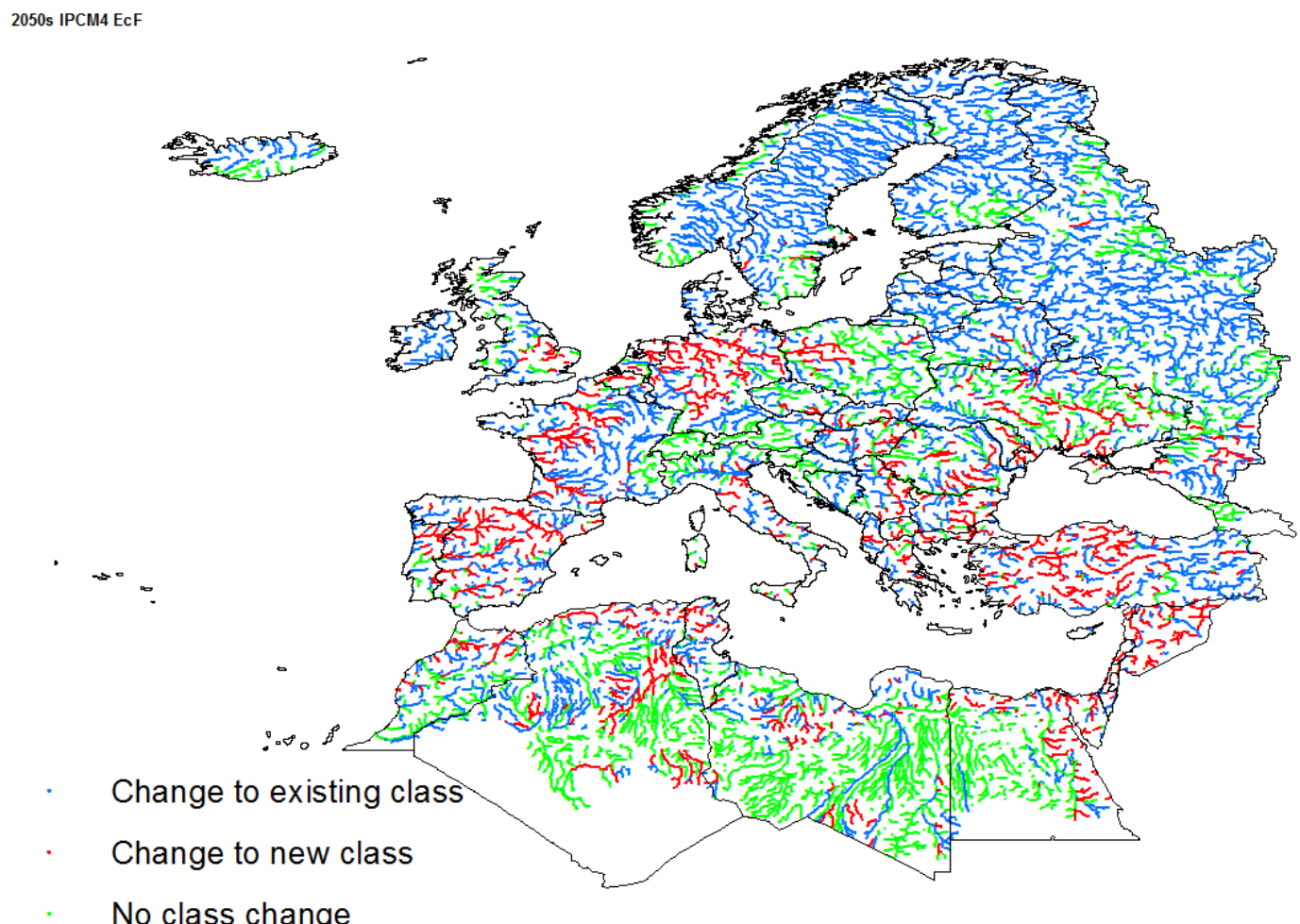

Figure 4 Class changes from Baseline to IPCM4 EcF 2050s

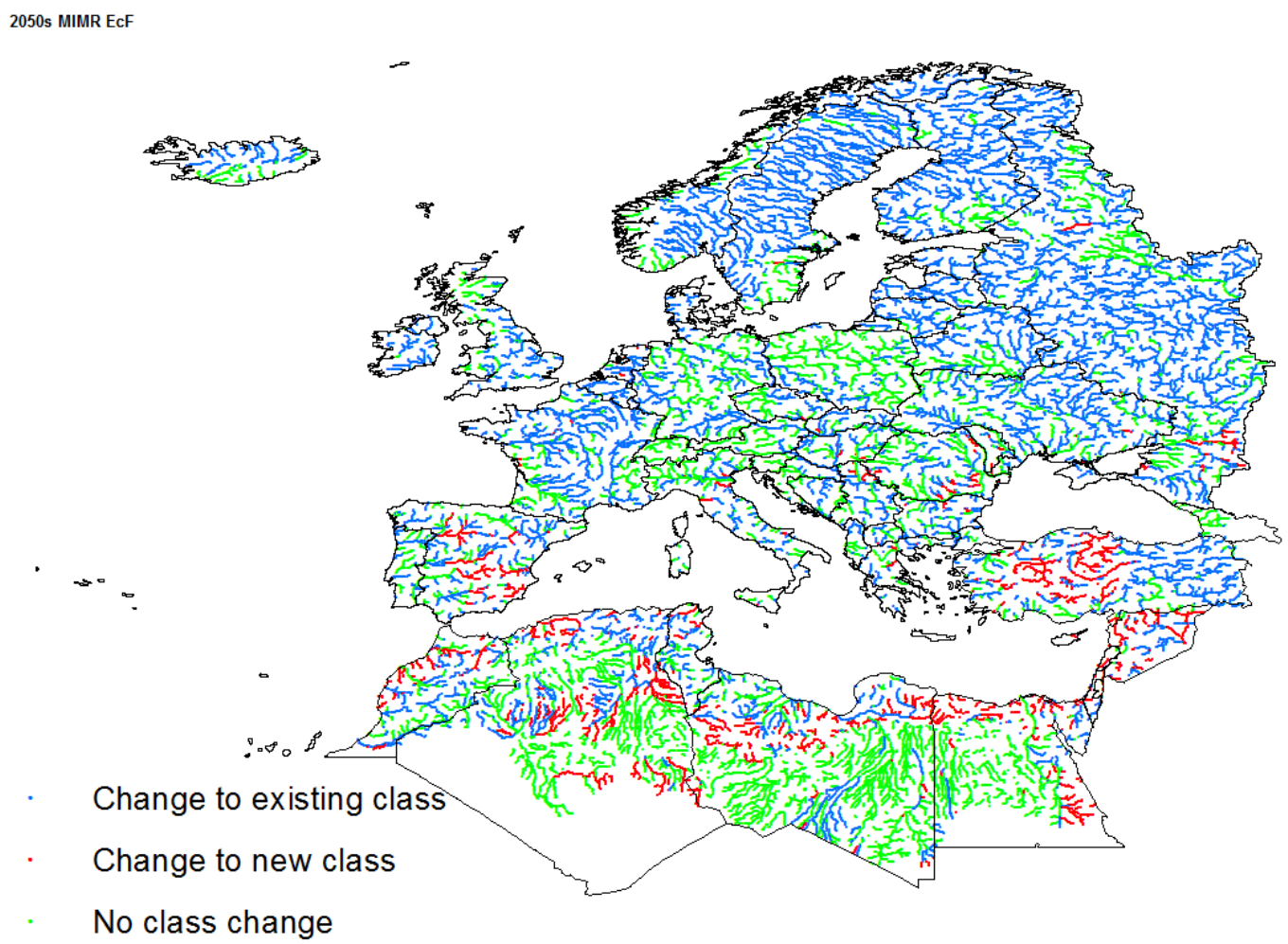

Figure 5 Class changes from Baseline to MIMR EcF 2050s 


\section{Discussion}

Results showed that many river reaches would keep broadly similar eco-hydrological regimes (within $30-50 \%$ of the river network length) or regime would be more similar to another type (within $40-50 \%$ of the network length). For the remaining reaches (within 10-20\% of the network length), eco-hydrological regime would change to novel form not currently seen in Europe, with potential to create new river ecosystems.

Given the shared model and data of this paper with Laizé et al. (2014), present results are discussed with reference to the previous study (note: baseline was naturalised 1961-1990, unlike the present baseline, which is observed 1961-1990). Firstly, Laizé et al. (2014) found that two thirds of the European river network would be at medium or high ecological risk due to flow alteration by $2050 \mathrm{~s}$. While risk classes do not necessarily translate directly in terms of river type change, for many scenarios, the overall proportion of river length changing/not changing is similar, with six runs out of eight having c. 30\% no change, but two roughly split $50-50 \%$. This would suggest that some amount of flow alteration could occur without necessarily leading to a new rive type.

Secondly, results show variability in geographical location of river types, and of change types (ie no change, change to existing class, or change to new class) mostly along a west-east central belt, while the "outer rim" is much more consistent across scenarios. This is also quite consistent with patterns observed in Laizé et al. (2014), which showed that the main influence of socio-economics occurred in a similar west-east belt. Despite the geographical variability, breakdowns of river types or of change types (see Tables 3 and 4) are much more consistent, also echoing findings from Laizé et al. (2014).

Thirdly, patterns are primarily driven by climate, with socio-economics being a secondary driver, although a significant one (similar to Laizé et al., 2014). The socio-economic scenarios with least changing river length is the sustainable future $\mathrm{SuE}$. This was the scenario with least risks due to flow alterations in Laizé et al. (2014). The other three scenarios give essentially the same results (except for the security-focused FoE under IPCM4, which is very similar to IPCM4 SuE). This gives partial insight on the question of how much river infrastructures and regulation could mitigate climate impact, although one need to keep in mind that while dams are included in the model, other structures or modifications may not be. Studies like Dunbar et al., 2010Dunbar et al. (2010) showed that ecosystems of physically modified rivers are more sensitive to flow change than natural rivers, so while such rivers may be more controllable with their structures, they may also be more vulnerable.

These results need to be understood against the study limitations: (i) river ecosystems are not controlled by hydrology only (e.g. water quality or climate play a major role); (ii) different eco-hydrological types may not necessarily correspond to different ecosystems; (iii) patterns may be partly related to the characteristics of the underlying data (eg monthly metrics) and model (eg spatial extent, grid resolution). (iv) the negative or positive impact of having disappearing, changing, or emerging types is not necessarily known.

However, the present approach could be used to identify appropriate targets conditions for river restoration (for example, for the purpose of meeting the European Water Framework Directive (WFD) objectives) within the context of changing reference conditions. Traditionally, target are set with reference to past ecological states, but under changing water 
availability (water use or climate), those conditions may be unrealistic due to ignoring the system variability.

There is some direct evidence that past environmental change has ecological impacts. For example, a few decades ago the Little Egret (Egretta garzetta) was a very rare visitor to the UK from the Mediterranean, but this bird is now a common sight around the coasts of southern England and Wales due to warmer conditions (Moss et al., 2009). However, clearly there is no direct evidence of future changes thus one needs to rely on model projections (e.g. Thuiller et al., 2008). Furthermore, species numbers and ecosystem diversity rely on complex dynamics, food web interactions and energy partitioning. Thus external drivers, such as river flow, will only partially explain the character of future ecosystems. Nevertheless, appropriate flow regime is an important determinant, and without appropriate flows ecosystems cannot persist. Indeed natural perturbation such as floods (McMullen \& Lytle, 2012) and droughts (Bogan \& Lytle, 2011) can create novel ecosystems. It is therefore reasonable to state that if a river change from one eco-hydrological flow type to another there is a potential for new ecosystems, especially if it results loss of existing species. However, the actual ecosystem that develops depends on the ability of new species to arrive that can exploit available niches. Furthermore, it is not known if the new ecosystem will meet the criterion of self-sustaining (Morse et al., 2014).

Much depends on relationship between flow alteration and ecological impact (Arthington et al., 2006). If the response is a step function and the threshold is crossed, such as loss of overbank flows that support riparian vegetation or to provide fish access to floodplain spawning areas, a dramatic alteration of the ecosystem is more likely. We have some insight into how the ecosystem may change from the existing and destination eco-hydrological river types. The baseline type for the River Rhone is class 5, with highest flows in late spring created by snow-melt, but with sustained flows all year. The destination type is class 7 with high flows predominantly in winter (though some in the autumn) and regular low flow period in summer. Thus there is an overall reduction in annual flow volume, a shift from spring to winter high flow and a new low flow period. These alterations could have significant implications for fish migration, invertebrate emergence as adults and macrophyte reproduction. 


\section{Conclusions}

This study has projected that eco-hydrological characteristics of European rivers are very likely to alter substantially in some areas by 2050 because of a combination of climate change and increased water use.

Some rivers are most likely to transform to become river types that existed elsewhere in Europe under baseline conditions. Other rivers will have an eco-hydrological signature that is unlike any apparent in the baseline condition and so have the potential to form novel river ecosystems. This would create a significant issue under the European Water Framework Directive because the default is to maintain at or restore to near natural reference conditions (Acreman \& Ferguson, 2010). However, some European rivers are conserved under the European Habitats Directive for conditions created by long-term significant management, such as the River Itchen, UK (Acreman et al., 2014b).

A number of potential future research avenues were identified. Firstly, this paper focused on the wider European context, but the potential new eco-hydrological types identified therein may already exist outside Europe. One could first compare new eco-hydrological types to existing types based on observed flow data (eg from GRDC), then extend the approach beyond Europe. For example, Döll and Zhang (2010) used WaterGAP worldwide albeit generating fewer flow indicators and at much coarser spatial and temporal (annual) scales. Secondly, the degree to which European rivers' history (eg evidences from past centuries or millennia) could inform about the next century; the present approach could be used with longer-term hindcasts to characterise river types across the past and to investigate their eventual association with historical milestones (eg early industrialisation). Lastly, although this paper focused on ecosystems (ie which ones are likely to be lost, eg ephemeral Mediterranean, and which countries are at risk, eg Spain, Germany), it would be worthwhile investigating the most appropriate catchment-level mitigation measures to flow regime change with regards to hydrological functions, such as erosion or groundwater recharge.

Novel ecosystems do not need to be considered a threat to existing policy and management approaches. We need to take a more integrated approach to environmental management that is in tune with the current reality of rapid ecosystem change (Hobbs et al., 2014).

\section{Acknowledgements}

The authors gratefully acknowledge financial support for the project water SCenarios for Europe and NEighbouring States (SCENES) from the European Commission (FP6 contract 036822), and from the Natural Environment Research Council (NERC) through its National Capability funding to the Centre for Ecology and Hydrology. The views expressed in the paper are those of the authors, and not necessarily of the coordinating or funding bodies of the SCENES project.

\section{References}

Acreman MC, Arthington AH, Colloff MJ, Couch C, Crossman ND, Dyer F, Overton IC,Pollino C, Stewardson M, Young W. 2014a. Environmental flows - natural, hybrid and novel riverine ecosystems. Frontiers in Ecology and Environment 12 (8): 466-473.

Acreman MC, Overton IC, King J, Wood P, Cowx I, Dunbar MJ, Kendy E, Young W. 2014b. The changing role of science in environmental flows. Hydrological Sciences Journal 59: 3-4, 433-450.

Acreman MC, Ferguson A. 2010. Environmental flows and European Water Framework 
Directive. Freshwater Biology 55: 32-48.

Alcamo J, Döll P, Henrichs T, Kaspar F, Lehner B, Rösch T, Siebert S. 2003. Global estimates of water withdrawals and availability under current and future "business-as-usual" conditions. Hydrological Sciences Journal 48 (3): 339-348.

Arthington AH. 2012. Environmental flows: saving rivers in the Third Millennium. University of California Press. Berkeley.

Arthington AH, Bunn SE, Poff NL, Naiman RJ. 2006. The challenge of providing environmental flow rules to sustain river ecosystems. Ecological Applications 16: 4, 13111318.

Auerbach DA, Buchanan BP, Alexiades AV, Anderson EP, Encalada AC, Larson EI, McManamay RA, Poe GL, Walter MT, Flecker AS. 2016. Towards catchment classification in data-scarce regions. Ecohydrology. DOI: 10.1002/eco.1721

Bogan MT, Lytle DA. 2011. Severe drought drives novel community trajectories in desert stream pools. Freshwater Biology 56: 2070-2081.

Butchart, S.H.M. and 33 others 2010 Global Biodiversity: Indicators of Recent Declines. Science 328: 5982, 1164-1168.

Bunn SE, Arthington AH. 2002. Basic principles and ecological consequences of altered flow regimes for aquatic biodiversity. Environ. Manage. 30: 4, 492-507.

Chen I-C, Hill JK, Ohlemüller R, Roy DB, Thomas CD. 2011. Rapid range shifts of species associated with high levels of climate warming. Science 333: 1024-1026.

Dunbar MJ, Pedersen ML, Cadman D, Extence C, Waddingham J, Chadd R, Larsen SE. 2010. River discharge and local-scale physical habitat influence macroinvertebrate LIFE scores. Freshwater Biology 55(1): 226-242.

Döll P, Zhang J. 2010. Impact of climate change on freshwater ecosystems: a global-scale analysis of ecologically relevant river flow alterations. Hydrology and Earth System Sciences 14: 783-799.

Feld C K, de Bello F, Dolédec S. 2014. Biodiversity of traits and species both show weak responses to hydromorphological alteration in lowland river macroinvertebrates. Freshwater Biology 59: 233-248.

Gordon AD. 1999. Classification (2nd edition). London, Chapman \& Hall.

Hobbs RJ, Arico S, Aronson J, Baron JS, Bridgewater P, Cramer VA, Epstein PR, Ewel JJ, Klink JA, Lugo AE, Norton D, Ojima D, Richardson DM, Sanderson EW, Valladares F, Vilà M, Zamora R, Zobel M. 2006. Novel ecosystems: theoretical and management aspects of the new ecological world order. Global Ecology and Biogeography 15: 1-7.

Hobbs RJ, Higgs E, Harris JA. 2009. Novel ecosystems: implications for conservation and restoration. Trends in Ecology and Evolution 24: 11, 599-605.

Hobbs RJ, Higgs E, Hall CM, Bridgewater P, Chapin III SF, Ellis EC, Ewel JJ, Hallett LM, Harris J, Hulvey KB, Jackson ST, Kennedy PL, Kueffer C, Lach L, Lantz TC, Lugo AE, Mascaro J, Murphy SD, Nelson CR, Perring MP, Richardson DM, Seastedt TR, Standish RJ, Starzomski BM, Suding KN, Tognetti PM, Yakob L, Yung L. 2014. Managing the whole landscape: historical, hybrid, and novel ecosystems. Frontiers in Ecology and the Environment 12: 557-564.

IPCC. 2014. Climate Change 2014: Synthesis Report. Contribution of Working Groups I, II and III to the Fifth Assessment Report of the Intergovernmental Panel on Climate Change [Core Writing Team, RK Pachauri and LA Meyer (eds.)]. IPCC, Geneva, Switzerland, 151 pp.

Kundzewicz Z, Mata L, Arnell NW, Doll P, Jimenez B, Miller K, Oki T, Sen Z, Shiklomanov I. 2008. The implications of projected climate change for freshwater resources and their management. Hydrological Sciences Journal 53: 1, 3-10. 
Laizé C, Acreman MC, Schneider C, Dunbar MJ, Hougton-Carr H, Flörke M, Hannah D. 2014. Projected flow alteration and ecological risk for pan-European rivers. Rivers Research and Applications 30 (3): 299-314.

Laizé CLR, Hannah DM. 2010. Modification of climate-river flow associations by basin properties. Journal of Hydrology 389(1-2): 186-204.

Lamouroux N, Olivier JM, Capra H, Zylberblat M, Chandesris A, Roger P. 2006. Fish community changes after minimum flow increase: testing quantitative predictions in the Rhone River at Pierre-Benite, France. Freshwater Biology 51: 1730-1743.

Lewis SL, Maslin MA. 2015. Defining the Anthropocene. Nature 519: 171-180.

Lytle DA, Poff NL. 2004. Adaptation to natural flow regimes. Trends in Ecology and Evolution 19: 2, 94-100.

Markovic D, Carrizo S, Freyhof J, Cid N, Lengyel S, Scholz M, Kasperdius H, Darwall W. 2014. Europe's freshwater biodiversity under climate change: distribution shifts and conservation needs. Diversity and Distribution 20: 1097-1107. doi:10.1111/ddi.12232

MEA (Millennium Ecosystem Assessment). 2005. Ecosystems and human well-being: synthesis. Washington, DC: Island Press.

McMullen LE, Lytle DA. 2012. Quantifying invertebrate resistance to floods: a global-scale meta-analysis. Ecological Applications 22: 8, 12-25.

Morse NB, Pellissier P, Cianciola E, Brereton R, Sullivan M, Shonka N, Wheeler T, McDowell W. 2014. Novel ecosystems in the Anthropocene: a revision of the novel ecosystem concept for pragmatic applications. Ecology and Society 19: 2, 12.

Moss B, Hering D, Green AJ, Adoud A, Becares E, Beklioglu M, Bennion H. 2009. Climate change and the future of freshwater biodiversity in Europe: a primer for policy-makers. Freshwater Reviews 2 (2):103-130.

Okruszko T, Duel H, Acreman MC, Grygoruk M, Flörke M, Schneider C. 2011. Broad-scale ecosystem services of European wetlands - overview of current situation and future perspectives under different climate and water management scenarios. Hydrological Sciences Journal 56: 8.

Olden J, Kennard MJ, Bradley JP. 2012. A framework for hydrologica classification with a review of methodologies and applications in ecohydrology. Ecohydrology 5: 503-518.Poff NL, Allan JD, Bain MB, Karr JR, Prestegaard KL, Richter BD, Sparks RE, Stromberg JC. 1997. The natural flow regime: a paradigm for river conservation and restoration. Bioscience 47: 769-784.

Poff NL, Zimmerman JKH. 2010. Ecological responses to altered flow regimes: a literature review to inform the science and management of environmental flows. Freshwater Biology 55:194-205.

Richter BD, Baumgartner JV, Powell J, Braun DP. 1996. A Method for Assessing Hydrological Alteration within Ecosystems. Conserv. Biol. 10:1163-1174.

Schinegger R, Trautwein C, Melcher A, Schmutz S. 2012. Multiple human pressures and their spatial patterns in European running waters. Water and Environment Journal, 26(2):261-273.

Souchon Y, Sabaton C, Deibel R, Reiser D, Kershner J, Gard M, Katopodis C, Leonard P, Poff NL, Miller WJ, Lamb BL. 2008. Detecting biological responses to flow management: Missed opportunities; Future directions. River Research and Applications 24: 506-518.

Southwood TRE. 1977. Habitat, the templet for ecological strategies. Journal of Animal Ecology 46: 337-365.

Thuiller W, Albert C, Araujo M, Berry P, Cabeza M, Guisan A, Hickler G, Midgely J, Paterson FM, Schurr FM, Sykes MT, Zimmermann NE. 2008. Predicting global change 
impacts on plant species' distributional. Perspectives in Plant Ecology Evolution and Systematics 9: 3-4, 137-152.

Vorosmarty CJ, McIntyre PB, Gessner MO, Dudgeon D, Prusevich A, Green P, Glidden S, Bunn SE, Sullivan CA, Reidy Liermann C, Davies PM. 2010. Global threats to human water security and river biodiversity. Nature 467:555-562.

Ward JH. 1963. Hierarchical grouping to optimize an objective function. Journal of the American statistical association 58(301): 236-244. 